\title{
PENGARUH INTELLECTUAL CAPITAL, NON PERFORMING FINANCING (NPF), \& FINANCING TO DEPOSIT RATIO (FDR) TERHADAP KINERJA KEUANGAN BANK SYARIAH TAHUN 2014-2018
}

\author{
Jenny Risky Aghnia Caesar \\ Universitas Negeri Surabaya \\ jennycaesar@mhs.unesa.ac.id
}

\begin{abstract}
The development of the financial performance of Islamic banks in Indonesia in the 2014-2018 period has increased and developed over the past twenty years, the development of Islamic banks' financial performance has not met the targeted expectations of above 5\% (ojk.go.id). Judging from the market share of Islamic banks have met the target but it is caused by the conversion of conventional banks into sharia and not because of organic growth (www.infobanknews.com). Compared to conventional banks, Islamic banks only channeled total loans of $R p 291.18$ trillion from $R p$ 4,782 trillion of total national banking loans or only $6.08 \%$ of total national banking loans which caused the growth of the Islamic finance industry to slow down. So this study intends to see the effect of intellectual capital, non-performing financing (NPF), and financing to deposit ratio (FDR) on the financial performance of Islamic banks. This study uses multiple linear regression analysis techniques with a sample of all Islamic banks registered at the OJK and meets the specified criteria to produce as many as 8 Islamic banks that are eligible to be tested. The results of this study indicate that the variables HCE, SCE, CEE and FDR do not affect ROA while the NPF variable is the only variable that has a negative influence on ROA. Customers use the $N P F$ value to see whether the bank can return credit from a bank's debtors, a high NPF value indicates the level of bank failure in returning credit that negatively impacts $R O A$.
\end{abstract}

Keyword: financial performance; financing to deposit ratio; intelectual capital; non performing financing

\section{PENDAHULUAN}

Lembaga perbankan berfungsi sebagai penghimpun dan penyalurkan dana masyarakat dalam mendukung serta meningkatkan taraf hidup rakyat melalui pertumbuhan ekonomi, stabilitas nasional dan pemerataan pembangunan demi upaya ke arah kesejahteraan masyarakat yang menyeluruh banyak memerlukan berbagai inovasi terbaru dalam bidang perbankan dalam menggerakan roda perekonomian Nasional (ojk.go.id, 2017).

Keuangan syariah telah berkembang lebih dari dua puluh tahun di Indonesia. Dalam perkembangan kinerja keuangannya masih belum sesuai apa yang diharapkan oleh OJK (Otoritas Jasa Keuangan) yang diharapkan di atas 5\%. Dilihat dari market share bank umum syariah di Indonesia yang ditargetkan sebesar 5\% telah terpenuhi, akan tetapi hal tersebut terjadi bukan karena organic growth melainkan disebabkan oleh konversi bank umum konvensional menjadi syariah sehingga market share bank umum syariah saat ini mencapai 8,26 (Supriyanto, 2018). Total kredit yang disalurkan perbankan nasional yang sebesar Rp 4.782 triliun dibandingkan penyaluran kredit perbankan syariah yang hanya sebesar Rp 291,18 triliun atau hanya sebanyak 6,08\% dari total penyaluran total kredit perbankan nasional yang menjadi penyebabkan lambannya pertumbuhan industri keuangan syariah karena masih belum terintegrasi peraturan-peraturan yang dikeluarkan. (liputan6.com, 2018).

Gambar 1 menunjukkan ROA bank umum konvensional dibandingkan ROA bank umum syariah memiliki perbedaan yang besar hal ini menunjukkan bahwa pasar yang besar yaitu penduduk yang beragama Islam sebanyak kurang lebih 207 juta jiwa (bps.go.id, 2010) tidak menjamin kinerja keuangan bank umum syariah tinggi. Karena perbedaan tingkat ROA yang signifikan sehingga menjadi fokus peneliti terdahulu untuk lebih dominan meneliti mengenai faktor-faktor yang dapat memengaruhi adanya keputusan dalam melakukan investasi. 
Jenny Risky Aghnia Caesar \& Yuyun Isbanah. Pengaruh Intellectual Capital, Non Performing Financing (NPF), \& Financing To Deposit Ratio (FDR) terhadap Kinerja Keuangan Bank Syariah Tahun 2014-2018

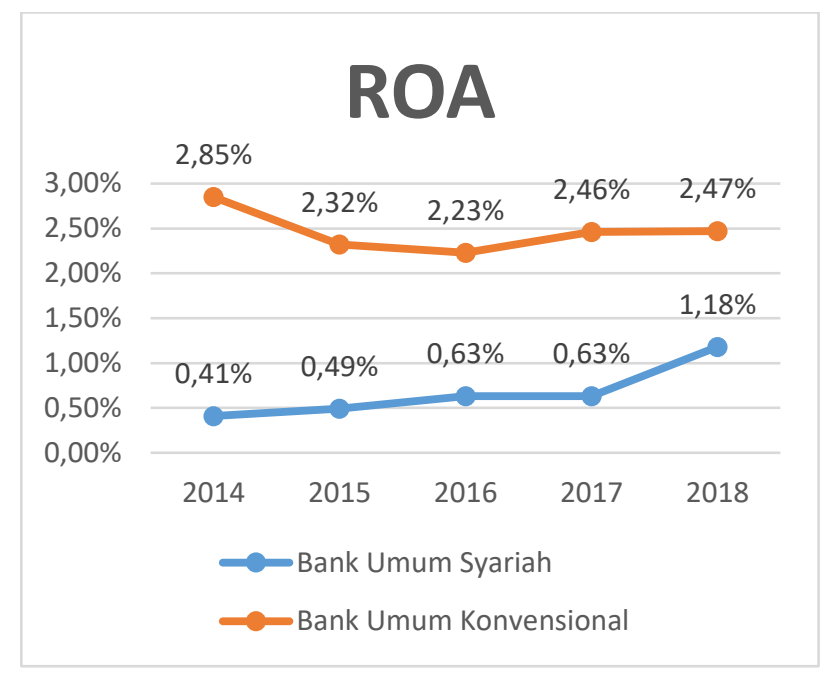

Sumber: ojk.go.id (2019, data diolah)

\section{Gambar 1. GRAFIK ROA BANK UMUM SYARIAH DAN BANK UMUM KONVENSIONAL 2014-2018}

Intellectual Capital (IC) memiliki beberapa indikator. Indikator yang digunakan dalam penelitian ini adalah Human Capital Efficiency (HCE), Structural Capital Efficiency (SCE), dan Capital Employed Efficiency (CEE) (Ulum, 2009:47). Secara empiris telah dibuktikan bahwa Human Capital Efficiency (HCE) berpengaruh positif signifikan terhadap meningkatnya produktifitas pada perusahaan dibuktikan oleh penelitian yang dilakukan oleh Al-Musali \& Ismail (2014); Fathi, Farahmand, \& Khorasani (2013); Kuspinta \& Husaini (2018) dan Ozkan, Cakan, \& Kayacan (2016) HCE berpengaruh positif terhadap ROA. sedangkan hasil penelitian Devi, Khairunnisa, \& Budiono (2017) dan Islamiyah (2015) HCE berpengaruh negatif terhadap ROA. Tetapi dalam penelitian Kartika \& Hatane (2013) dan Sirapanji \& Hatane (2015) HCE tidak signifikan terhadap ROA.

Structural capital Efficiency (SCE) muncul setelah melalui nilai dan menghadapi suatu proses dalam organisasi yang menunjukkan bahwa adanya fokus organisasi dalam pengembangan dan pembaharuan nilai secara internal maupun eksternal untuk masa mendatang (Ulum, 2009:48). Hasil penelitian Devi et al. (2017); Fathi et al. (2013); Islamiyah (2015); Kartika \& Hatane (2013); Kurfi, Udin, \& Bahamman (2017); Kuspinta \& Husaini (2018); Sirapanji \& Hatane (2015) membuktikan bahwa antara SCE dengan ROA memiliki hubungan positif. Sedangkan penelitian yang dilakukan oleh Al-Musali \& Ismail (2014) dan Ozkan et al. (2016) SCE tidak memiliki pengaruh atau negatif signifikan terhadap ROA.

Capital Employed Efficiency (CEE) menunjukkan adanya peran setiap unit terhadap pencapaian value added pada kinerja keuangan (Ulum, 2009:49). Dari penelitian Devi et al. (2017); Fathi et al. (2013); Islamiyah (2015); Kartika \& Hatane (2013); Kurfi et al. (2017); Kuspinta \& Husaini (2018); Ozkan et al. (2016); Sirapanji \& Hatane (2015) membuktikan adanya hubungan positif antara CEE dengan ROA. Tetapi penelitian Al-Musali \& Ismail (2014) CEE tidak berpengaruh terhadap ROA.

Non Performing Financing (NPF) merupakan proses suatu bank dalam memprediksi risiko-risiko internal terkait dengan kegagalan pengembalian kredit dari debitur. Semakin tinggi nilai NPF bank umum syariah mengakibatkan semakin rendah nilai ROA bank tersebut (Suhadak, Bachri, \& Saifi, 2013). Pernyataan tersebut sesuai dengan hasil penelitian Ch (2017); Langka, Safitri, \& Kardinal (2016); Suhadak et al. (2013) yang menghasilkan bahwa nilai NPF berpengaruh negatif. Sedangkan di hasil penelitian Susilowibowo \& Zulifiah (2014) diketahui bahwa variabel NPF berpengaruh positif terhadap ROA. Tetapi pada Hanania (2015); Lemiyana \& Litriani (2016); Sabir, Ali, \& Hamid (2012); Widyaningrum (2015) menyatakan bahwa NPF memiliki pengaruh negatif signifikan terhadap ROA.

Financing to Deposit Ratio (FDR) fungsi suatu bank dalam melihat kemampuan pada pembayaran deposan, membayar hutang-hutangnya, serta memenuhi permintaan kredit yang diajukan (Suhadak et 
al., 2013). Hasil penelitian yang dilakukan Langka et al. (2016) dan Sabir et al. (2012) FDR berpengaruh positif terhadap ROA. Sedangkan dalam penelitian Ch (2017) dan Suhadak et al. (2013) menemukan apabila FDR berpengaruh negatif kepada variabel ROA. Sedangkan, hasil berbeda dapat ditemukan pada kajian empiris yang dilakukan oleh Lemiyana \& Litriani (2016) dan Widyaningrum (2015) didapatkan hasil bahwa FDR tidak berpengaruh terhadap ROA.

Tujuan untuk melakukan penelitian ini adalah untuk mengetahui apakah variabel Intellectual Capital, Non Performing Financing (NPF), Financing to Deposit Ratio (FDR) memiliki pengaruh terhadap kinerja keuangan bank syariah pada tahun 2014-2018.

\section{KAJIAN PUSTAKA DAN PENGEMBANGAN HIPOTESIS}

\section{Signalling Theory}

Perusahaan yang memiliki informasi positif dalam operasional perusahaannya akan membuat manajer perusahaan terdorong untuk menyampaikan kepada calon investor merupakan pernyataan dari Signalling theory (Brigham \& Houston, 2014:54). Perusahaan yang memiliki informasi mengenai FDR (financing to deposit ratio) dan NPF (non performing financing) dengan nilai yang baik dapat berpengaruh pada return on asset (ROA) menjadi baik pula sehingga memberikan nilai positif terhadap ROA (Brigham \& Houston, 2014:140).

\section{Stakeholder Theory}

Seluruh stakeholder pada dasarnya memiliki hak untuk diberi sarana informasi tentang aktifitasaktifitas organisasi yang memengaruhi mereka adalah maksud dari Stakeholder Theory (Deegan, 2004) dalam (Ulum, 2009). Konsep stakeholder digunakan sebagai cara dalam membantu manajer korporasi demi upaya meningkatkan nilai yang diakibatkan oleh seluruh kegiatan perusahaan dan meminimalkan kerugian bagi stakeholder. Perwujudan potensi perusahaan dan pengelolaan yang baik harus memanfaatkan nilai atas seluruh potensi perusahaan tersebut sehingga menciptakan value added (VA) secara optimal yang pada masa yang akan datang dapat mendorong kinerja keuangan perusahaan sebagai pemenuhan kepentingan stakeholder (Ulum, 2009:25).

\section{Bank Syariah}

Perbankan syariah adalah suatu sistem perbankan yang memiliki konsep dan menggunakan hukum Islam sebagai dasar dalam pengoperasiannya (syariah). Hukum dasar Islam yang digunakan mengacu pada pungutan maupun pinjaman dengan bunga serta adanya larangan untuk melakukan investasi bagi usaha-usaha yang dikategorikan tidak sesuai dengan syariah (haram), di mana hal tersebut tidak dilakukan oleh bank konvensional (Muchtar, Rahmidani, \& Siwi, 2016:119).

\section{Kinerja Keuangan}

Kinerja keuangan merupakan hasil yang diperoleh oleh suatu bank dalam mengelola sumber dayanya dalam mencapai tujuannya (Kasmir, 2016:196). Rasio yang digunakan adalah Return On Asset (Kasmir, 2016:196), rasio profitabilitas yang memberikan suatu tingkatan ukuran manajemen yang lebih efektif yang ditunjukkan oleh laba yang diperoleh dari pendapatan investasi maupun penjualan sehingga perusahaan dapat mewujudkan keuntungan dari laba secara maksimal.

\section{Intellectual Capital}

Intellectual capital merupakan pengelolaan aset tidak berwujud (intangible asset) karena tidak mengandung adanya nilai keuangan namun dapat dikonversikan ke dalam nilai perusahaan. Setelah beberapa waktu IC mengalami perkembangan teori oleh banyak ahli, menghasilkan kesimpulan bahwa IC merupakan segala sesuatu yang berkaitan dengan pengalaman, kekayaan dan pengetahuan informasi serta intelektual yang dapat menciptakan keuntungan bagi perusahaan. IC merupakan aset tidak berwujud yang dapat memberikan value bagi perusahaan dan masyarakat dalam hal waralaba, hak cipta, hak paten maupun hak atas kekayaan intelektual perusahaan itu sendiri (Ulum, 2009:46). 
Jenny Risky Aghnia Caesar \& Yuyun Isbanah. Pengaruh Intellectual Capital, Non Performing Financing (NPF), \& Financing To Deposit Ratio (FDR) terhadap Kinerja Keuangan Bank Syariah Tahun 2014-2018

\section{Komponen Intellectual Capital}

Peneliti hakikatnya akan melakukan identifikasi pada tiga konstruk utama dari IC (Intellectual Capital) yaitu HC (human capital), SC (structural capital) dan CC (customer capital), yang mana IC menggunakan model perhitungan Value Added Intellectual Coefficient (VAIC) (Pulic 1997; Sirapanji \& Hatane, 2015). Model perhitungan Value Added Intellectual Coefficient (VAIC) digunakan untuk memberikan informasi-informasi tentang efisiensi penciptaan nilai dari perusahaan yang berupa aset berwujud (tangible asset) dan aset tidak berwujud (intangible assets) yang berasal dari perusahaan tersebut. Komponen IC dihitung dalam melihat kemampuan perusahaan untuk demi menciptakan value added (VA), di mana VA adalah indikator yang mampu memprediksi dan menilai keberhasilan kegiatan bisnis dan menunjukkan tingkatan penciptaan nilai yang dihasilkan (value creation). Nilai VA dihitung dengan rumus VA = OUT-IN (Ulum, 2009:47).

\section{Human Capital Efficiency (HCE)}

Human capital (HC) merupakan komponen yang penting dalam modal intelektual, selain itu HC adalah sumber keterampilan dan pengetahuan maupun kompetensi pada suatu organisasi atau perusahaan (Ulum, 2009:48). Penghitungan HCE dapat dilihat dalam rumus (1)

$$
\mathrm{HCE}=\frac{V A}{H C}
$$

Keterangan:

$\mathrm{VA}=$ Value added

$\mathrm{HC}=$ Human Capital (beban karyawan)

\section{Structural Capital Efficiency (SCE)}

Structural capital (SC) merupakan suatu proses organisasi atau perusahaan dalam memenuhi pola kerja perusahaan yang didukung oleh strukturnya yang mendukung usaha karyawan dalam menghasilkan kinerja berbasis intelektual secara optimal (Ulum, 2009:49). Penghitungan SCE dilihat dalam rumus (2).

$\mathrm{SCE}=\frac{S E}{V A}$

Keterangan:

$\mathrm{VA}=$ Value added

$\mathrm{SC}=$ Structural Capital $: \mathrm{VA}-\mathrm{HC}$

\section{Capital Employed Efficiency (CEE)}

CEE yaitu unsur modal intelektual yang berperan untuk memberikan value secara nyata pada perusahaan maupun organisasi. CEE (customer capital) sendiri sangat erat kaitannya dengan relasi antar perusahaan dengan mitranya, maupun perusahaan dengan pelanggan, baik hubungan baik dengan perusahaan milik pemerintah maupun masyarakat, sehingga dapat menumbuhkan loyalitas dan kerjasama yang baik (Ulum, 2009:50). Penghitungan CEE dilihat dalam rumus (3).

$\mathrm{CEE}=\frac{V A}{C E}$.

Keterangan:

$\mathrm{VA}=$ Value added

$\mathrm{CE}=$ Capital Employed $:$ dana yang tersedia (ekuitas, laba bersih)

\section{Non Performing Financing}

Rasio Non Performing Financing adalah rasio yang digunakan untuk mengetahui kemampuan manajemen bank yang terkait dengan pengelolaan kredit bermasalah untuk debitur. Risiko kredit yang diakibatkan ketidakjelasan pengembalian kredit atau tidak dapat dilunasi oleh debitur dapat menyebabkan masalah yang cukup signifikan bagi bank (Suhadak et al., 2013). 
$\mathrm{NPF}=\frac{\text { Pembiayaan bermasalah }}{\text { total pembiayaan }} \times 100 \%$

\section{Financing to Deposit Ratio}

Dalam mengukur kemampuan bank untuk membayar hutang dan membayar deposannya secara menyeluruh, maka perhitungannya menggunakan rasio FDR, di mana FDR dapat mengukur keseluruhan hutang dan kewajiban pembayaran liabilitas serta dapat memenuhi permintaan kredit yang diajukan (Suhadak et al., 2013).

$\mathrm{FDR}=\frac{\text { total pembiayaan }}{\text { Dana pihak ketiga }} \times 100 \%$

\section{Hubungan antar Variabel}

Human capital efficiency (HCE) adalah aset yang tidak berwujud di mana berupa kreativitas karyawan, inovasi sumber daya manusia, serta kemampuan intelektual, dan peranan karyawan dalam menggunakan keahliannya dengan optimal yang dapat menghasilkan nilai tambah terhadap perusahan dan dapat memengaruhi peningkatan pengelolaan aset perusahaan serta Return on asset (ROA) perusahaan dengan signifikan. Menurut Al-Musali \& Ismail (2014) adanya hubungan positif yang signifikan antara Human capital efficiency (HCE) dengan kinerja keuangan (ROA), hasil penelitian ini didukung oleh Fathi et al. (2013); Kuspinta \& Husaini (2018); Ozkan et al. (2016). Apabila HCE meningkat akan menghasilkan tenaga kerja yang berkualitas sehingga meningkatkan kinerja keuangan. Tetapi hasil penelitian tersebut tidak didukung oleh hasil penelitian Sirapanji \& Hatane (2015), yaitu memiliki hubungan negatif antara HCE dengan kinerja keuangan (ROA) karena HCE menurun menghasilkan tenaga kerja yang kurang berkualitas sehingga menurunkan kinerja keuangan. Berbeda dengan hasil penelitian Devi et al. (2017) yang menemukan bahwa HCE tidak berpengaruh terhadap kinerja keuangan (ROA) karena kinerja keuangan tidak dipengaruhi oleh variabel human capital sehingga mendapati pengaruh negatif signifikan, yang kemudian pernyataan ini didukung oleh Islamiyah (2015) dan Kartika \& Hatane (2013).

\section{H1 : Human Capital Efficiency (HCE) berpengaruh positif terhadap Return On Assets (ROA).}

Structural capital efficiency (SCE) dinilai dapat menjadi penghubung human capital (HC) dalam mewujudkan peningkatan nilai tambah (value added) perusahaan. Variabel Structural capital berdampak pada pengelolaan aset perusahaan yang kian baik yang membuat biaya produksi yang dikeluarkan akan semakin sedikit sehingga laba dapat meningkat serta kinerja perusahan membaik yang akan membuat Return on Asset (ROA) membaik pula. Men urut hasil penelitian Sirapanji \& Hatane (2015) menunjukkan hubungan yang positif antara SCE dengan variabel kinerja keuangan (ROA) hal tersebut terjadi karena variabel structural capital dapat membantu peningkatan pendapatan dalam proses kinerja keuangan perusahaan, hal ini juga dibuktikan pada studi empiris Devi et al. (2017); Fathi et al. (2013); Islamiyah (2015); Kartika \& Hatane (2013); Kurfi et al. (2017); Kuspinta \& Husaini (2018). Tetapi dalam penelitian yang dilakukan oleh Al-Musali \& Ismail (2014) didapatkan hasil tidak memiliki hubungan yang signifikan antara variabel SCE terhadap kinerja keuangan (ROA), pernyataan tersebut terjadi karena faktor pengaruh kinerja keuangan tidak dilihat dari variabel SCE sehingga hasil dari penelitian ini tidak signifikan, penelitian ini didukung oleh Ozkan et al. (2016).

\section{H2 : Structural Capital Efficiency (SCE) berpengaruh positif terhadap Return On Assets (ROA).}

Capital Employed Efficiency (CEE) merupakan suatu proses pengukuran dari Capital employed, di mana penghitungan Capital employed berasal dari total aset dikurangi kewajiban lancar yang memperlihatkan modal yang digunakan oleh perusahaan. Modal perusahaan dan total aset perusahaan akan saling memengaruhi, di mana apabila modal perusahaan meningkat maka total aset juga akan mengalami peningkatan sejalan dengan banyaknya modal perusahaan, hal ini juga akan memengaruhi pendapatan perusahaan, sehingga dapat diketahui juga peningkatan laba atas sejumlah aset yang dimiliki perusahaan yang diukur dengan Return On Asset (ROA). Stakeholder theory menyatakan 
Jenny Risky Aghnia Caesar \& Yuyun Isbanah. Pengaruh Intellectual Capital, Non Performing Financing (NPF), \& Financing To Deposit Ratio (FDR) terhadap Kinerja Keuangan Bank Syariah Tahun 2014-2018

apabila pemegang saham atau stakeholder memiliki hak terkait dengan segala informasi atas aktifitas didalam organisasi.

Menurut penelitian Sirapanji \& Hatane (2015) menunjukkan hasil positif pada CCE terhadap ROA, nilai CCE yang tinggi dinilai dapat memengaruhi ROA karena modal perusahaan yang digunakan adalah aset yang bernilai bagi kemampuan perusahaan dalam menghasilkan laba atau pendapatan bagi perusahaan tersebut, hal ini sejalan dengan pernyataan Devi et al. (2017); Fathi et al. (2013); Islamiyah (2015); Kartika \& Hatane (2013); Kurfi et al. (2017); Kuspinta \& Husaini (2018); Ozkan et al. (2016). Tetapi hasil penelitian yang dilakukan oleh Al-Musali \& Ismail (2014) yang mana menunjukkan bahwa CCE tidak memiliki hubungan yang signifikan terhadap kinerja keuangan, pernyataan tersebut terjadi karena faktor pengaruh kinerja keuangan tidak dilihat dari variabel CCE sehingga hasil dari penelitian ini tidak signifikan.

\section{H3 : Capital Employed Efficiency (CEE) berpengaruh positif terhadap Return On Assets (ROA).}

Hal yang paling terlihat apabila adanya peningkatan terhadap nilai NPF sehingga berdampak pada pembesaran biaya pada kegiatan perusahaan, sehingga menimbulkan potensi kerugian bank, dan memperlihatkan buruknya kualitas kredit bank yang menimbulkan pembengkakan pada jumlah kredit, di mana bank harus menanggung kerugian dalam kegiatan operasionalnya yang mengakibatkan penurunan laba (ROA) yang diperoleh bank. Nilai NPF berada di bawah 5\% menunjukkan bank tersebut memiliki kualitas kredit bank yang baik. Menurut Suhadak et al. (2013) variabel NPF berpengaruh negatif terhadap kinerja keuangan (ROA) karena nilai NPF bank semakin rendah yang mengakibatkan semakin tinggi kinerja keuangan (ROA) tersebut, karena terdapatnya kredit bermasalah menyebabkan kredit yang disalurkan tidak banyak memberikan hasil, penelitian ini di dukung oleh Ch (2017) dan Langka et al. (2016). Tetapi hasil penelitian yang dilakukan oleh Susilowibowo \& Zulifiah (2014) di temukan hasil positif antara variabel NPF terhadap ROA. Sedangkan penelitian yang dilakukan oleh Sabir et al. (2012) mengemukakan hasil tidak ada signifikan antara variabel NPF terhadap kinerja keuangan (ROA) karena faktor pengaruh kinerja keuangan tidak dilihat dari variabel NPF sehingga hasil dari penelitian ini tidak signifikan, pernyataan ini didukung oleh Hanania (2015); Lemiyana \& Litriani (2016); Widyaningrum (2015).

\section{H4: Non Performing Financing (NPF) berpengaruh negatif terhadap Return On Assets (ROA).}

Kemampuan bank dalam menentukan dan menghitung pembayaran hutang-hutangnya serta membayar kembali pada deposan dan memenuhi permintaan kredit dihitung dengan rasio FDR. Nilai FDR yang dapat mendukung kemampuan bank dalam menghitung liabilitas perusahaannya yaitu yang berada di atas $80 \%$. Nilai FDR yang semakin tinggi memperlihatkan bahwa bank tersebut mampu membayar liability dan membayar kembali kepada deposannya. Menurut Sabir et al. (2012) telah ditemukan bahwa adanya hasil positif antara variabel FDR terhadap kinerja keuangan (ROA), yang disebabkan oleh pembiayaan yang dikeluarkan oleh bank kepada calon nasabah berjalan lancar, sehingga akan berdampak pada kinerja keuangan (ROA) yang juga meningkat. Menurut Suhadak et al. (2013) variabel FDR terhadap kinerja keuangan (ROA) memiliki hubungan yang negatif, disebabkan oleh besarnya pembiayaan yang diberikan oleh bank akan tetapi pembiayaan tersebut tidak diimbangi dengan penambahan dan peningkatan jumlah dana pihak ketiga (DPK) sehingga menyebabkan besarnya piutang yang belum diterima akan mengurangi kas, penelitian ini didukung oleh Ch (2017). Sedangkan Widyaningrum (2015) menyatakan bahwa FDR tidak memiliki hasil yang signifikan terhadap variabel kinerja keuangan (ROA) dikarenakan pembiayaan yang disalurkan oleh pihak bank tidak menimbulkan peningkatan secara efektif serta optimal, hal tersebut memengaruhi pembiayaan non-lancar yang mana juga sejalan dengan total pembiayaan yang dikeluarkan bank, hasil studi empiris tersebut juga didukung oleh Langka et al. (2016) dan Lemiyana \& Litriani (2016).

H5 : Financing to Deposit Ratio (FDR) berpengaruh positif terhadap Return On Assets (ROA). 


\section{METODE PENELITIAN}

Penelitian ini menggunakan sebuah pendekatan yaitu pendekatan kausalitas, dalam penelitian ini menganalisis ada tidaknya pengaruh variabel independen (Human Capital Efficiency, Structural Capital Efficiency, Capital Employed Efficiency, Non Performing Financing dan Financing to Deposit Ratio) terhadap variabel dependen yaitu kinerja keuangan (ROA). Jenis data yang digunakan yaitu secara kuantitatif, sumber data yang digunakan dalam penelitian yaitu data primer dan sekunder. Penelitian ini lebih menggunakan sumber data sekunder yang berasal dari laporan keuangan tahunan Bank Umum Syariah selama periode 2014-2018, yang dipublikasikan melalui Otoritas Jasa Keuangan (OJK) pada website www.ojk.go.id. Berdasarkan kriteria sampel yang digunakan dalam penelitian ini didapatkan 8 sampel bank syariah. Sampel yang sudah ditentukan dikalikan dengan tahun penelitian yang sebanyak 5 periode (2014-2018) sehingga total data pengamatan yang didapat sebanyak 40 . Metode analisis yang digunakan menggunakan uji normalitas, uji multikoloneritas, uji autokorelasi, uji heteroskedastisitas, uji linearitas, analisis regresi linier berganda. Serta menggunakan uji hipotesisi yang terdiri dari uji F, uji t dan koefisien determinasi (Adjusted $\mathrm{R}^{2}$ )

\section{HASIL DAN PEMBAHASAN}

Tabel 1.

HASIL UJI ASUMSI KLASIK

\begin{tabular}{|c|c|c|c|c|c|c|c|}
\hline Jenis & Tolerance & VIF & Sig. & $\begin{array}{l}\text { Asymp } \\
\text {. Sig. }\end{array}$ & $\begin{array}{l}\text { Durbin- } \\
\text { Watson }\end{array}$ & $\begin{array}{l}\text { SRD. Error of } \\
\text { the Estimate }\end{array}$ & $\begin{array}{c}\mathbf{R} \\
\text { Square }\end{array}$ \\
\hline Uji Normalitas & & & & ,056 & & & \\
\hline \multicolumn{8}{|c|}{ Uji Multikolinieritas } \\
\hline Ln_HCE &, 779 & 1,283 & & & & & \\
\hline Ln_SCE & 229 & 4,367 & & & & & \\
\hline Ln_CEE & 240 & 4,158 & & & & & \\
\hline Ln_NPF & ,827 & 1,208 & & & & & \\
\hline Ln_FDR & ,723 & 1,383 & & & & & \\
\hline Uji Autokorelasi & & & & & 1,713 & 1,27785 & \\
\hline Run Test & & & ,873 & & & & \\
\hline \multicolumn{8}{|c|}{ Uji Heteroskedastisitas } \\
\hline (Constant) & & & 268 & & & & \\
\hline Ln_HCE & & & 994 & & & & \\
\hline Ln_SCE & & & ,383 & & & & \\
\hline Ln_CEE & & & 298 & & & & \\
\hline Ln_NPF & & & 910 & & & & \\
\hline Ln_FDR & & & 254 & & & & \\
\hline Uji Linearitas & & & & & & & ,438 \\
\hline
\end{tabular}

Sumber: Output SPSS (data diolah)

\section{Hasil Uji Normalitas}

Grafik histrogram digunakan dalam mencari hasil uji normalitas sehingga dapat menghasilkan grafik normal pronanility plot berupa garis lurus dan pada Uji Kolmogorov-Smirnov memiliki nilai K-S > 0,05 sehingga menunjukkan bahwa data tersebut tidak berdistribusi secara normal sehingga perlu dilakukan transformasi data.

\section{Hasil Uji Multikolinieritas}

Uji multikolinieritas menunjukkan hasil bahwa semua variabel memiliki nilai VIF dibawah 10 dan nilai tolerance yang berada di atas 0,1. Dapat dikatakan bahwa model regresi tidak mengalami multikolinieritas. 
Jenny Risky Aghnia Caesar \& Yuyun Isbanah. Pengaruh Intellectual Capital, Non Performing Financing (NPF), \& Financing To Deposit Ratio (FDR) terhadap Kinerja Keuangan Bank Syariah Tahun 2014-2018

\section{Hasil Uji Autokorelasi}

Uji Autokorelasi yang menggunakan uji Durbin-Watson (DW test) menghasilkan bahwa dalam penelitian ini terdapat autokorelasi dikarenakan posisi $\mathrm{dL}<\mathrm{DW}<\mathrm{dU}$ sehingga diperlukan run test. Hasil setelah dilakukan run test menunjukkan nilai Asymp. Sig. (2-tailed) > 0,05 dengan demikian masalah autokorelasi terselesaikan dengan uji run test sehingga analisis regresi linear dapat dilanjutkan.

\section{Hasil Uji Heteroskedastisitas}

Hasil uji heteroskedastisitas yang menggunakan grafik plot menunjukan tidak adanya pola yang terbentuk serta titik-titik menyebar diatas dan dibawah angka 0 pada sumbu Y. Serta pada uji glejser untuk lebih memastikan secara statistik menghasilkan semua variabel memiliki nilai sig. $>0,05$ sehingga menunjukan tidak terdapat heteroskedastisitas.

\section{Hasil Uji Linearitas}

Uji Lagrange Multiplier digunakan untuk mencari uji linearitas yaitu dapat menunjukan nilai $\mathrm{c}^{2}$ hitung sebesar 40 x 0,438 $=17,520$. Sedangkan nilai $\mathrm{c}^{2}$ tabel dengan $\mathrm{df}=35$ pada nilai signifikansi 0,05 sebesar 49,802 . Sehingga nilai $c^{2}$ hitung $<c^{2}$ tabel menunjukan bahwa diterimanya model linear.

\section{Regresi Linier Berganda}

Model persamaan regresi linier berganda pada penelitian ini dapat dilihat di rumus (6).

$\mathrm{Y}=-0,804 X_{4}+e$

\section{Hasil Uji Statistik F}

Nilai signifikan dari hasil uji $F$ sebesar 0,008 di mana hasil tersebut berarti kurang dari 0,05 menunjukan bahwa variabel HCE, SCE, CEE, NPF, dan FDR secara bersama-sama (simultan) berpengaruh kinerja keuangan.

\section{Hasil Uji T}

Tabel 2 hasil uji t menunjukkan hanya variabel NPF yang berpengaruh negatif terhadap kinerja keuangan dengan nilai t hitung $-3,436$ dan signifikansi $0,002<0,05$. Sedangkan untuk variabel SCE, HCE,CEE, dan FDR tidak memiliki pengaruh pada kinerja keuangan bank syariah periode 2014-2018.

Tabel 2.

\section{HASIL UJI STATISTIK T}

\begin{tabular}{lrcc}
\hline Model & \multicolumn{1}{l}{ B } & \multicolumn{1}{c}{ t } & Sig. \\
\hline (Constant) & $-5,829$ &,- 442 &, 661 \\
LN_HCE &, 412 & 1,619 &, 115 \\
LN_SCE &,- 333 &,- 323 &, 749 \\
LN_CEE &,- 516 &,- 312 &, 757 \\
LN_NPF &,- 8804 & $-3,436$ &, 002 \\
LN_FDR & 1,515 &, 521 &, 606 \\
Uji F & & &, 008 \\
Adjusted $R^{2}$ & & &, 260 \\
\hline
\end{tabular}

Sumber: Output SPSS (data diolah)

\section{Hasil Koefisien Determinasi $\left(\mathbf{R}^{2}\right)$}

Hasil koefisien determinasi (Adjusted $R$ ) bernilai 0,260 atau 26\%. Hasil tersebut menjelaskan bahwa sebanyak $26 \%$ di mana variabel CE, SCE, CEE, NPF, dan FDR dapat memengaruhi ROA. Sisanya yaitu sebesar $74 \%$ diasumsikan dipengaruhi oleh model lain yang tidak dijabarkan dan menjadi unsur dalam penelitian ini. 


\section{Pengaruh Human Capital Efficiency terhadap Kinerja Keuangan}

Variabel HCE tidak dapat memengaruhi pertumbuhan tren kinerja keungan dalam perbankan syariah meskipun telah terdaftar pada Otoritas Jasa Keuangan (OJK) periode 2014-2018. HCE merupakan aset perusahaan yang tak berwujud dalam bentuk kemampuan karyawan pada hal kreativitas, inovasiinovasi serta kekayaan intelektual yang dimiliki oleh karyawan. Hasil ini menunjukkan bahwa HCE yang dihasilkan bank syariah memiliki nilai yang rendah di mana human capital kurang memiliki inovasi dalam menghasilkan solusi terbaik bagi perusahaan sehingga tidak bisa memengaruhi kinerja keuangan bank syariah tersebut. Hasil penelitian ini berlawanan dengan teori stakeholder yang menyatakan bahwa seluruh pemegang saham harus memiliki sarana informasi yang disediakan sebagai bentuk pemenuhan hak yaitu mengenai bagaimana aktifitas organisasi memengaruhi para pemegang saham (Deegan, 2004) dalam (Ulum, 2009), dengan nilai HCE yang rendah menunjukkan bahwa hak untuk diberikannya informasi perusahaan kepada stakeholder berkurang. Sehingga hasil ini menunjukkan bahwa tinggi rendahnya nilai HCE tidak memberikan sinyal kepada nasabah sehingga tidak mampu memengaruhi kinerja keuangan.

Penelitian ini sejalan dengan studi empiris yang dilakukan oleh Devi et al. (2017) di mana value added yang dikeluarkan oleh perusahaan dalam bentuk anggaran belum mampu mewujudkan kinerja keuangan yang baik, sebagai proyeksi dari intellectual capital, faktanya hasil uji HCE secara parsial tidak memengaruhi kinerja keuangan perusahaan, karena tidak mampu berdiri sendiri, atau membutuhkan faktor atau variabel pengukuran lain dalam keberhasilan perusahaan. Penelitian lain yang mendukung yaitu hasil penelitian dari Islamiyah (2015) yang mengindikasikan value added yang dikeluarkan oleh perusahaan dalam bentuk anggaran belum mampu mewujudkan kinerja keungan bagi perusahaan manufaktur. Selanjutnya, hasil empiris dari Kartika \& Hatane (2013) mengungkapkan penyebab kemungkinan HCE tidak signifikan karena penggunaan physical capital dinilai lebih menguntungkan dibandingkan intangible capital yaitu human capitalnya. Perusahaan cenderung tidak menanamkan model untuk masa depan dengan memperhatikan unsur manusianya, namun lebih kepada unsur sarana dan prasarana yang mendukung kontinuitas kinerja perusahaan pada masa berjalan (secara operasional). Hal ini akhirnya berpengaruh kepada pengurangan human capital yang berdampak pada signifikansi pengaruh pemanfaatan kualitas sumber daya manusia, kemudian upah, gaji maupun tunjangan cenderung kurang dan kurangnya motivasi karyawan, sehingga human capital tidak dapat memberikan value added pada perusahaan (Kartika \& Hatane (2013).

\section{Pengaruh Structural Capital Efficiency terhadap Kinerja Keuangan}

Berdasarkan hasil penelitian SCE tidak memiliki pengaruh pada kinerja keuangan suatu bank syariah yang terdaftar pada Otoritas Jasa Keuangan (OJK) periode 2014-2018. Nilai SCE yang rendah menunjukkan bahwa kurangnya pengetahuan manajer dalam mengolah modal manusia yang dimiliki sehingga SDM dalam bank syariah tidak dapat memaksimalkan kemampuan mereka dalam produktivitas bank syariah yang mengakibatkan nilai kinerja keuangan bank syariah rendah akan tetapi bisa juga tidak ada pengaruh apapun terhadap kinerja keuangan. Hasil ini tidak cocok dengan teori stakeholder karena nilai SCE yang rendah menunjukkan informasi yang didapat oleh stakeholder berkurang sehingga hak para stakeholder berkurang. Hasil ini menunjukkan bahwa tinggi rendahnya nilai SCE tidak memberikan sinyal kepada nasabah sehingga tidak mampu memengaruhi kinerja keuangan.

SCE merupakan suatu bentuk ukur untuk variabel SC (Structural Capital) agar menghasilkan satu rupiah dibutuhkan berapa nilai SC, nilai SCE kemudian menunjukkan apakah pengelolaan aset perusahaan semakin baik atau tidak yang memengaruhi biaya produksi. Nilai SCE yang tinggi menghasilkan nilai yang positif terhadap kinerja keuangan karena menunjukkan pengelolaan dalam biaya produksi maksimal sehingga menunjukkan nilai yang positif terhadap kinerja keuangan. Hasil pengolahan data penelitian berbeda dengan teori SCE terhadap kinerja keuangan. Hasil penelitian ini di dukung oleh penelitian Al-Musali \& Ismail (2014) di mana menunjukkan bahwa SCE dan ROA tidak memiliki hubungan yang signifikan. Kajian empiris Ozkan et al. (2016) menambahkan bahwa peningkatan kemampuan untuk menghasilkan laba perusahaan tidak dipengaruhi oleh stuctural capital. 
Jenny Risky Aghnia Caesar \& Yuyun Isbanah. Pengaruh Intellectual Capital, Non Performing Financing (NPF), \& Financing To Deposit Ratio (FDR) terhadap Kinerja Keuangan Bank Syariah Tahun 2014-2018

Jumlah SCE tidak berpengaruh karena pengelolaan aset perusahaan juga harus diikuti oleh peningkatan structure capital yang baik seperti pengolaan sistem, prosedur,dan database yang baik, sehingga dapat menghambat tumbuhnya value added (VA) (Ozkan et al., 2016).

\section{Pengaruh Capital Employed Efficiency terhadap Kinerja Keuangan}

Hasil pengolahan data penelitian menunjukkan hipotesis alternatif variabel $\mathrm{CEE}\left(\mathrm{H}_{1}\right)$ ditolak dan $\mathrm{H}_{0}$ diterima, artinya CEE tidak terdapat pengaruh pada kinerja keuangan suatu bank syariah. Nilai variabel CEE yang rendah menunjukkan bahwa bank syariah tidak dapat mengelolah capital employednya secara efisien sehingga pegawai bank syariah tidak dapat berkontribusi secara maksimal dalam menghasilkan pendapatan yang mengakibatkan nilai kinerja keuangan bank syariah rendah, tetapi bisa juga tidak memberikan pengaruh positif ataupun negatif terhadap kinerja keuangan. Hasil ini bertentangan dengan teori stakeholder yang menyatakan para stakeholder memiliki hak untuk diberikan informasi tentang bagaimana aktifitas perusahaan. Dengan hasil CEE yang rendah menghasilkan informasi yang diberikan kepada stakeholder kurang. Hasil ini menunjukkan bahwa tinggi rendahnya nilai CCE tidak memberikan sinyal kepada nasabah sehingga tidak mampu memengaruhi kinerja keuangan.

Hasil penelitian ini sesuai dengan hasil penelitian Al-Musali \& Ismail (2014) yang berindikasi bahwa CEE bukan aset utama dalam perusahaan yang dapat digunakan untuk meningkatkan kinerja perusahaan, hasil ini sejalan dengan kondisi yang dialami oleh perusahaan di mana aset tidak berwujud belum dapat dilaporkan maupun diukur untuk meningkatkan kinerja keuangan perusahaan. Selanjutnya, hasil penelitian juga menunjukkan bahwa kinerja keuangan juga tidak dipengaruhi oleh relasi kemitraan dengan pihak eksternal maupun usaha perusahaan dalam kegiatan promosi, peningkatan gaji karyawan hingga periklanan yang dilakukan dalam peningkatan aset dan pengelolaan sumber daya perusahaan.

\section{Pengaruh Non Performing Financing terhadap Kinerja Keuangan}

Hasil penelitian menunjukkan variabel NPF menerima hipotesis alternatif $\mathrm{H}_{0}$ dan menolak $\mathrm{H}_{1}$, artinya NPF memiliki pengaruh yang negatif terhadap kinerja keuangan. Nilai NPF yang tinggi maka menunjukkan kinerja keuangan bank tersebut semakin rendah, karena nilai NPF yang semakin tinggi akan memperbesar biaya dan menunjukkan kualitas kredit yang buruk, sehingga bank syariah akan memberikan sinyal yang tidak baik kepada nasabah. Hal ini sesuai dengan signalling theory yaitu menyampaikan informasi keadaan bank saat ini untuk menarik nasabah agar melakukan investasi. Hal ini menunjukkan tingginya nilai NPF membuat nasabah tidak mempercayai bank sehingga bank dianggap gagal mengelola keuangan.

Nilai NPF menunjukkan rasio pembayaran kredit yang dilakukan oleh nasabah, apabila nilai NPF semakin tinggi menunjukkan pembayaran terhambat dan bank menanggung kerugian akibat hal tersebut, sehingga kinerja keuangan daripada ROA akan menurun. Hasil penelitian yang ditemukan pada kajian milik Suhadak et al. (2013) yang menemukan bahwa nilai NPF memiliki pengaruh negatif signifikan dalam kaitannya dengan nilai kredit nasabah, hal ini berarti adanya hambatan dalam pembayaran oleh debitur dan bank harus menanggung kerugian tersebut, dengan kata lain kredit yang disalurkan tidak berwujud hasil yang diharapkan dari kredit oleh bank. Sementara itu, penelitian yang dilakukan oleh Langka et al. (2016) menunjukan apabila hasil dari kredit yang berpengaruh negatif dan signifikan terhadap Return On Asset (ROA) dapat terjadi jika pinjaman yang dilakukan oleh nasabah tidak dapat menghasilkan laba dan gagal dikembalikan oleh bank sehingga mengalami kerugian dan penurunan tren laba. Penelitian Langka et al. (2016) juga didukung oleh hasil penelitian Ch (2017).

\section{Pengaruh Financing to Deposit Ratio terhadap Kinerja Keuangan}

Hasil ujia pada FDR secara parsial menunjukan apabila $\mathrm{H}_{0}$ diterima, sedangkan $\mathrm{H}_{1}$ ditolak, hal ini berarti variabel perhitungan FDR tidak memengaruhi ROA. Hasil ini menunjukkan bahwa kemampuan bank yang dihasilkan dalam membayar hutang-hutangnya tidak maksimal, sehingga para nasabah tidak mempercayai bank untuk berinvestasi. Hal ini berkebalikan dengan signalling theory yang menyatakan informasi keadaan bank saat ini untuk menarik nasabah agar melakukan investasi. Hal ini menunjukkan 
tinggi rendahnya nilai FDR tidak memberikan sinyal kepada nasabah sehingga FDR tidak mampu untuk memengaruhi kinerja keuangan.

Hasil penelitian ini sesuai dengan kajian empiris Widyaningum (2015) yang menunjukan bahwa FDR pada perbankan berpengaruh negatif signifikan terhadap ROA yang disebabkan oleh saluran pembiayaan Bank Pembiayaan Rakyat Syariah (BPRS) yang belum dapat berjalan secara optimal dan efektif, sehingga terjadi peningkatan pada pembiayaan non-lancar sejalan dengan total pembiayaan BPRS. Hal tersebut disebabkan karena adanya ketidaksiapan dalam penerapan prinsip kehati-hatian oleh pihak manajemen BPRS dalam melakukan seleksi calon nasabah pembiayaan tersebut. Penelitian Widyaningrum tersebut juga didukung oleh hasil temuan Lemiyana \& Litriani (2016).

\section{KESIMPULAN}

Penelitian ini menyimpulkan bahwa NPF merupakan satu-satunya variabel yang berpengaruh signifikan negatif terhadap ROA bank syariah periode 2014-2018. Variabel HCE tidak memengaruhi ROA bank syariah periode 2014-2018. Variabel SCE tidak memengaruhi ROA bank syariah periode 2014-2018 Variabel CEE tidak memengaruhi ROA bank syariah periode 2014-2018. Variabel FDR tidak memengaruhi ROA bank syariah periode 2014-2018. Hal ini disebabkan para nasabah tidak melihat maupun menggunakan variabel HCE, SCE, CEE, dan FDR sebagai acuan dalam pertimbangan untuk menggunakan jasa bank syariah selama periode 2014-2018. Sehingga pihak bank syariah diharapkan untuk meningkatkan kinerja agar menghasilkan laba dan menekan nilai NPF sehingga dapat mengurangi kredit macet yang memberikan dampak terhadap ROA dan nasabah akan lebih tertarik untuk menggunakan jasa bank syariah. Penelitian selanjutnya dapat melibatkan variabel Biaya Operasional Pendapatan Operator (BOPO), Capital Adequacy Ratio (CAR), dan inflasi.

\section{DAFTAR PUSTAKA}

Al-Musali, M., \& Ismail, K. (2014). Intellectual Capital and its Effect on Financial Performance of Bank: Evidence from Saudi Arabia. International Journal of Accounting and Economics Studies, 164, 201-207. https://doi.org/10.1016/j.sbspro.2014.11.068

Brigham, E., \& Houston, J. (2014). Dasar-Dasar Manajemen Keuangan. Jakarta: Salemba Empat.

Ch, I. (2017). The Effect Of Financial Ratios On Islamic Rural Bank Performance In Indonesia. International Journal of Scientific \& Technology Research, 6(08), 384-390.

Devi, B. E., Khairunnisa, \& Budiono, E. (2017). Pengaruh Intellectual Capital Terhadap Kinerja Keuangan Perusahaan ( Studi Kasus Pada Perusahaan Elektronik, Otomotif dan Komponen yang Terdaftar di Bursa Efek Indonesia ( BEI ) Periode 2011-2015 ). E-Proceeding of Management ISSN : 2355-9357, 4(1), 491-500, Bandung.

Embu, W. S. (2018). Industri Keuangan Syariah RI Disebut Lamban, Ini Buktinya. Retrieved January 22, 2019, from https://www.liputan6.com/bisnis/read/3525998/industri-keuangan-syariah-ridisebut-lamban-ini-buktinya

Fathi, S., Farahmand, S., \& Khorasani, M. (2013). Impact of Intellectual Capital on Financial Performance in the Pharmaceutical Industry in Iran. International Journal of Accounting and Economics Studies, 2(1), 6-17.

Hanania, L. (2015). Faktor Internal Dan Eksternal yang Mempengaruhi Profitabilitas Perbankan Syariah dalam Jangka Pendek dan Jangka Panjang. Pebanas, 1(1), 151-168.

Institusi Perbankan di Indonesia. (2017). Retrieved January 19, 2019, from https://www.ojk.go.id/id/kanal/perbankan/ikhtisar-perbankan/Pages/Lembaga-Perbankan.aspx 
Jenny Risky Aghnia Caesar \& Yuyun Isbanah. Pengaruh Intellectual Capital, Non Performing Financing (NPF), \& Financing To Deposit Ratio (FDR) terhadap Kinerja Keuangan Bank Syariah Tahun 2014-2018

Islamiyah, S. (2015). Pengaruh Modal Intelektual dan Data Kelola Perusahaan Terhadap Kinerja Keuangan pada Efek Syariah. Jurnal Akuntansi UNESA, 3(2), 1-27.

Kartika, M., \& Hatane, E. (2013a). Pengaruh Intellectual Capital pada Profitabilitas Perusahaan Perbankan yang Terdaftar di Bursa Efek Indonesia Pada Tahun 2007-2011. Business Accounting Review, 1(2), 14-25.

Kartika, M., \& Hatane, E. S. (2013b). Pengaruh Intellectual Capital Pada Profitabilitas Perusahaan Perbankan Yang Terdaftar Di Bursa Efek Indonesia Pada Tahun 2007-2011. Business Accounting Review, 1(2), 14-25.

Kasmir. (2016). Analisa Laporan Keuangan. Jakarta: PT RajaGrafindo Persada.

Kurfi, S. U. A., Udin, N. M., \& Bahamman, S. (2017). The Impact of Intellectual Capital on the Financial Performance of Listed Nigerian Food Products Companies. Accounting and Taxation, 9(11), 147-160. https://doi.org/10.5897/JAT2017.0246

Kuspinta, T. D., \& Husaini, A. (2018). Pengaruh Intellectual Capital Terhadap Profitabilitas Perusahaan (Studi Pada Perusahaan Manufaktur yang Terdaftar di Bursa Efek Indonesia Periode Tahun 20142016). Jurnal Administrasu Bisnis (JAB), 56(1), 164-170.

Langka, J., Safitri, E., \& Kardinal. (2016). Pengaruh CAR, FDR, dan NPF Terhadap ROA pada Bank Umum Syariah di Indonesia Periode 2012-2016. Jurnal Ekonomi Dan Bisnis, 6(1), 1-11.

Lemiyana, \& Litriani, E. (2016). Pengaruh NPF, FDR, BOPO Terhadap Return On Asset (ROA) Bank Umum Syariah. I-Economic, 2(1), 31-49.

Muchtar, B., Rahmidani, R., \& Siwi, M. (2016). Bank dan Lembaga Keuangan Lain. Jakarta: Kencana.

Ozkan, N., Cakan, S., \& Kayacan, M. (2016). Intellectual Capital and Financial Performance: A Study of the Turkish Banking Sector. Borsa Istanbul Review, 17(3), 190-198. https://doi.org/10.1016/j.bir.2016.03.001

Penduduk Menurut Wilayah dan Agama yang Dianut. (2010). Retrieved January 22, 2019, from https://sp2010.bps.go.id/index.php/site/tabel?tid=321

Sabir, M. M., Ali, M., \& Hamid, A. H. (2012). Pengaruh Rasio Kesehatan Bank Terhadap Kinerja Keuangan Bank Umum Syariah dan Bank Konvensional di Indonesia. Jurnal Analisis, 1(1), 7986.

Sirapanji, O., \& Hatane, E. S. (2015). Pengaruh Value Added Intellectual Capital Terhadap Kinerja Keuangan dan Nilai Pasar Jasa Yang Terdaftar Di Bursa Efek Indonesia Tahun 2008 - 2013. Business Accounting Review, 3(1), 45-54. https://doi.org/10.1111/j.0022-3646.1985.00323.x

Suhadak, Bachri, S., \& Saifi, M. (2013). Pengaruh Rasio Keuangan Terhadap Kinerja Keuangan Bank Syariah. Jurnal Administrasu Bisnis (JAB), 1(2), 177-185. Retrieved from http://administrasibisnis.studentjournal.ub.ac.id/index.php/jab/article/view/55/1607

Supriyanto, E. B. (2018). Perbankan Syariah: Kinerja yang Buruk karena Tata Kelola. Retrieved January 22, 2019, from https://infobanknews.com/analisis/perbankan-syariah-kinerja-yangburuk-karena-tata-kelola/

Susilowibowo, J., \& Zulifiah, F. (2014). Pengaruh Inflasi, BI Rate, Capital Adequacy Ratio (CAR), Non Performing Financial (NPF), Biaya Operasional dan Pendapatan Operasional (BOPO) 
Terhadap Profitabilitas Bank Umum Syariah Periode 2008-2012. Jurnal Ilmu Manajemen, 2(3), 759-770.

Ulum, I. (2009). Intellectual Capital. Yogyakarta: Graha Ilmu.

Widyaningrum, L. (2015). Pengaruh CAR, NPF, FDR, dan OER Terhadap ROA Pada Bank Pembiayaan Rakyat. Jurnal Ekonomi Syariah Teori Dan Terapan, 2(12), 970-985. 